\section{The Selby Fellowship}

THE Selby fellowship has been established to bring graduates of high promise and proved capacity for research to work in the laboratories of universities or research institutions in Australia. The fellowship may be awarded in any branch of physical or biological science, and is tenable at any university or research institution in Australia, normally for one full year of work. Candidates must have taken their first university degree, and have had preliminary research experience, at some university or universities in a country other than Australia. In general, they should hold a Ph.D. degree or have equivalent status and experience, but the fellowship will not normally be given to those who have already held a senior research award. Applicants should be less than thirty years of age on July $l$ in the year in which his application is received. The fellowship will carry a stipend of $£ 1,500$ (Australian) per annum. The costs of the Fellow's travel to Australia, and back to his country of origin at the conclusion of the fellow. ship, will be provided, up to a limit of $£ A 500$, ineluding dependants, if any. Applications should be sent to the Assistant Secretary, Gordon Street, Canberra City, A.C.T., before July 30.

\section{Challenger Society Grants for Marine Biology or Oceanography}

The Challenger Society has announced that it is prepared to make small grants for research in marine biology or oceanography at a recognized laboratory during the year June 1961-62. Applications, accompanied by details of the proposed research, should reach the Honorary Secretary, Challenger Society, National Institute of Oceanography, Wormley, Godalming, Surrey, not later than July 14.

\section{The Training of Biochemists}

THe Biochemical Society is organizing a colloquium on "The Training of Biochemists", on July 13, during the course of the Society's two-day meeting in Oxford (July 13-14). Included in the programme will be the following topics and speakers: biochemistry as an honours degree subject (Prof. S. V. Perry); the graduate biochemist and industry (Dr. W. F. J. Cuthbertson); university and departmental entrance requirements (Dr. Margaret Kerly); the teaching of biochemistry at Oxford (Prof. D. D. Woods); teaching in a small non-professorial department (Dr. G. R. Tristram); the M.Sc. course in biochemistry (Dr. E. M. Crook); summarizing remarks (Prof. F. C. Happold). Further information can be obtained from Dr. K. S. Dodgson, Department of Biochemistry, Physiology Institute, University College of South Wales and Monmouthshire, Newport Road, Cardiff.

\section{Announcements}

DR. W. E. SwINTon, of the Department of Palæontology, British Museum (Natural History), South Kensington, has been appointed head of the Division of Life Sciences at the Royal Ontario Museum, Toronto; Dr. Swinton will take up his new appointment in September.

Mr. B. L. J. Hart has succeeded Mr. Frank Worsfold as principal of the Computer Application Training Centre, of International Computers and Tabulators, Ltd., at Bradenham Manor. Mr. Hart was formerly a member of the International Computers and Tabulators' Computer Group, and is well known for his work on management and production control.

The British Society of Rheology and the NonDestructive Testing Group of the Institute of Physics and the Physical Society are holding a joint conference on "Rheological Techniques" in Llandudno during September 20-22. Further information can be obtained from Dr. Peter Lord, Royal College of Advanced Technology, Peel Park, Salford 5.

AN international conference on "Embryology", the fifth of its kind, is being sponsored by the editorial board of the Journal of Embryology and Experimental Morphology, and will be held in London at the Middlesex Hospital Medical School during September 18-21. Further information can be obtained from Dr. L. Brent, Department of Zoology, University College, Gower Street, London, W.C.1.

Jorntry the Science Council, the Physical Society and the Crystallographic Society of Japan are organizing an international conference on "Magnetism and Crystallography" at Kyoto during September 25-30. Further information can be obtained from either Prof. T. Nagamiya or Prof. S. Miyake, Organizing Committee of the International Conference on Magnetism and Crystallography, Science Council of Japan, Ueno Park, Tokyo, Japan.

AN informal conference organized jointly by the European Organization for Nuclear Research and the Max Planck Institute, Heidelberg, on "Fission and Spallation Phenomena and their Application to Cosmic Rays", will be held at the Organization's Laboratories, Meyrin (Geneva), during September 26-29. Further information can be obtained from the Scientific Conference Secretariat (E. W. D. Steel), CERN, Geneva 23, Switzerland.

The Mass Spectrometry Panel of the Institute of Petroleum, in conjunction with the American Society for Testing Materials (Committee $E$-14), is organizing a conference on "Mass Spectrometry" at the University of Oxford during September 12-15. Further information can be obtained from the organizing secretary, Mr. W. J. Brown, Instrumentation Division, Associated Electrical Industries (Manchester), Ltd., Trafford Park, Manchester 17.

The University of Chile and various societies of Santiago and Valparaiso are organizing an international symposium on "Tissue Transplantation", to be held in Santiago and Valparaiso, Chile, during August 30-September 2. The programme will cover: the genetical basis; immunological problems; present status and prospective applications of tissue transplantation. Further information can be obtained from Dr. Alberto P. Christoffanini, secretary of the organizing committee of the symposium, Maximo Humbser 567, Santiago, Chile.

Errata. In the article on "Technical Assistance to Overseas Countries" in Nature of June 17, p. 1039, par. 4 , lines 5 and 6 , for "directorates of the Overseas Services and the Overseas Geological Surveys" read "Directorate of Overseas Surveys and the Overseas Geological Surveys".

The sixth International Nematology Symposium will be held in Ghent during July 24-28. It is regretted that on p. 963 of the June 10 issue of Nature the word "Hæmatology" was printed for "Nematology". 